REV. 0

\title{
Chemical Hygiene Plan
}

\section{September 1994}

\section{DISCLAIMER}

This report was prepared as an account of work sponsored by an agency of the United States Government. Neither the United States Government nor any agency thereof, nor any of their employees, makes any warranty, express or implied, or assumes any legal liability or responsibility for the accuracy, completeness, or usefulness of any information, apparatus, product, or process disclosed, or represents that its use would not infringe privately owned rights. Reference herein to any specific commercial product, process, or service by trade name, trademark, manufacturer, or otherwise does not necessarily constitute or imply its endorsement, recommendation, or favoring by the United States Government or any agency thereof. The views and opinions of authors expressed herein do not necessarily state or reflect those of the United States Government or any agency thereof.

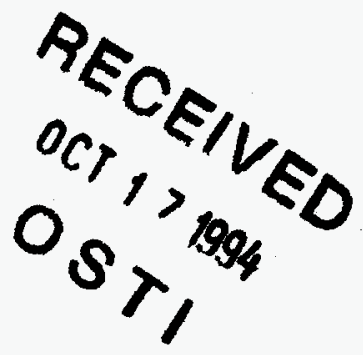




\section{INTENDED FOR PUBLIC RELEASE}

This report has been reproduced from the best available copy. Available in paper copy and microfiche.

Number of pages in this report: 52

DOE and DOE contractors can obtain copies of this report from:

Office of Scientific and Technical Information

P.O. Box 62

Oak Ridge, TN 37831

(615) 576-8401

This report is publicly available from:

National Technical Information Service Department of Commerce

5285 Port Royal Road

Springfield, VA 22161

(703) $487-4650$ 


\section{DISCLAIMER}

\section{Portions of this document may be illegible in electronic image products. Images are produced from the best available original document.}




\section{CHEMICAL HYGIENE PLAN}

\section{September 1994}

Prepared for

U.S. Department of Energy UMTRA Project Office Albuquerque, New Mexico

Prepared by Jacobs Engineering Group Inc. Albuquerque, New Mexico 


\section{TABLE OF CONTENTS}

Section

Page

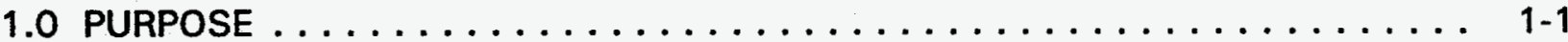

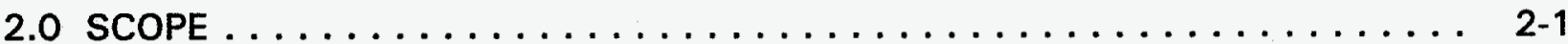

3.0 CHEMICAL HYGIENE PLAN $\ldots \ldots \ldots \ldots \ldots \ldots \ldots \ldots \ldots \ldots \ldots$

4.0 FACILITY USER TRAINING AND FACILITY RULES . . . . . . . . . . . . . . 4-1

4.1 Employee orientation $\ldots \ldots \ldots \ldots \ldots \ldots \ldots \ldots \ldots \ldots \ldots$ 4-1

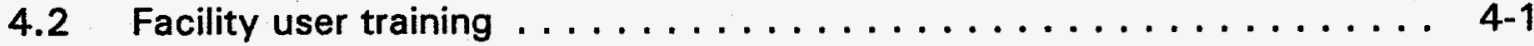

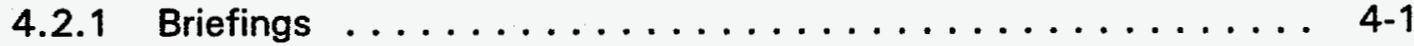

4.2.2 Specific task training ................... 4-1

4.3 Facility user duties . . . . . . . . . . . . . . . . . . . 4-2

4.4 General facility rules . . . . . . . . . . . . . . . . . . . . 4-2

4.5 Specific facility rules $\ldots \ldots \ldots \ldots \ldots \ldots \ldots \ldots \ldots \ldots \ldots$. . . . . . . . . . .

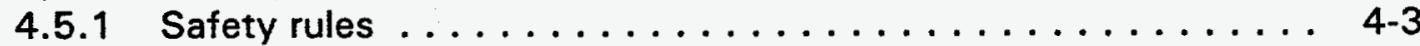

4.5.2 Chemical handling and storage ................ 4-4

4.5.3 Personal health and safety . . . . . . . . . . . . . . . 4-4

4.5 .4 Facility work ... . . . . . . . . . . . . . . . . . 4 4-4

4.5.5 Handling flammable solvents $\ldots \ldots \ldots \ldots \ldots \ldots \ldots \ldots$

5.0 CHEMICAL PROCUREMENT AND STORAGE $\ldots \ldots \ldots \ldots \ldots \ldots \ldots \ldots$

5.1 Procurement policy ....................... 5-1

5.2 Receipt of chemicals ..................... 5-1

5.2.1 Unacceptable shipments ................. 5-1

5.2 .2 Documenting received shipments $\ldots \ldots \ldots \ldots \ldots \ldots \ldots$ 5-1

5.3 Chemical storage procedures . . . . . . . . . . . . . . . . . 5-2

5.3.1 MSDS documentation ................... 5-2

5.3 .2 Acid storage ....................... 5-2

5.3.3 Flammable chemical storage ................. 5-2

5.3.4 Light-sensitive chemical storage . . . . . . . . . . . . 5-2

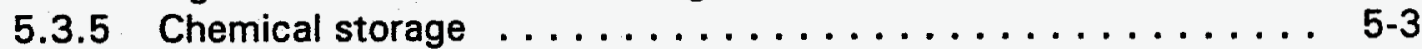

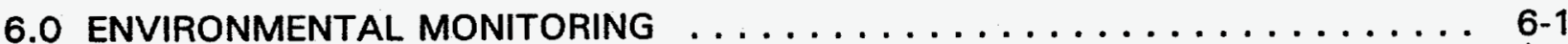

6.1 Personnel monitoring ....................... 6.1

6.1 .1 External exposure ...................... 6-1

6.1 .2 Internal exposure $\ldots \ldots \ldots \ldots \ldots \ldots \ldots \ldots \ldots \ldots . \ldots \ldots$

6.2 Facility monitoring program .................... 6-1

7.0 HOUSEKEEPING, STORAGE, AND INSPECTION $\ldots \ldots \ldots \ldots \ldots \ldots \ldots \ldots$

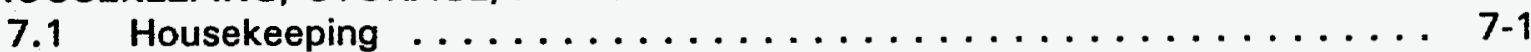

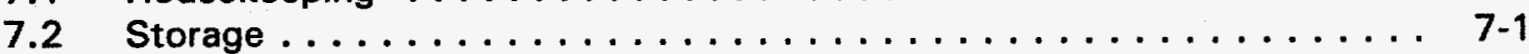

7.3 Inspection ......................... 7 .1 


\section{TABLE OF CONTENTS (Continued)}

Section

Page

8.0 MEDICAL PROGRAM $\ldots \ldots \ldots \ldots \ldots \ldots \ldots \ldots \ldots \ldots \ldots \ldots \ldots$ 8-1

8.1 General requirements $\ldots \ldots \ldots \ldots \ldots \ldots \ldots \ldots \ldots \ldots \ldots \ldots$ 8-1

8.2 Investigations, reports, and records $\ldots \ldots \ldots \ldots \ldots \ldots \ldots \ldots$ 8-1

9.0 PROTECTIVE APPAREL AND EQUIPMENT FOR REAGENT PREPARATION $\ldots \ldots$ 9-1

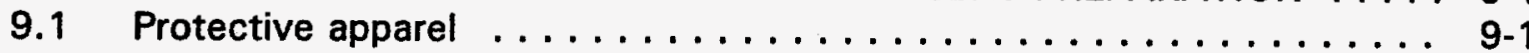

9.2 Protective equipment $\ldots \ldots \ldots \ldots \ldots \ldots \ldots \ldots \ldots \ldots \ldots$ 9-1

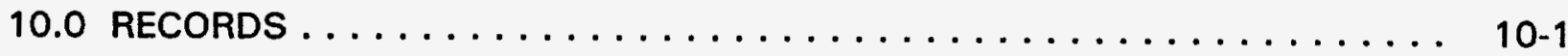

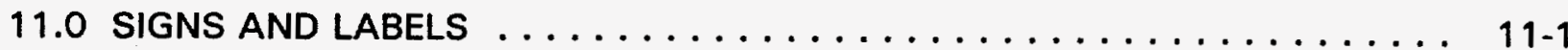

11.1 Signs $\ldots \ldots \ldots \ldots \ldots \ldots \ldots \ldots \ldots \ldots \ldots \ldots \ldots \ldots \ldots \ldots \ldots \ldots \ldots \ldots \ldots, 11-1$

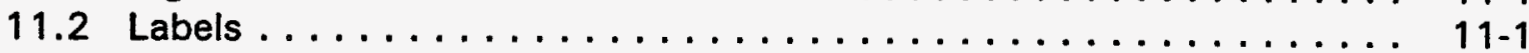

12.0 EMERGENCIES: FIRE AND INJURY $\ldots \ldots \ldots \ldots \ldots \ldots \ldots \ldots \ldots \ldots \ldots$ 12-1

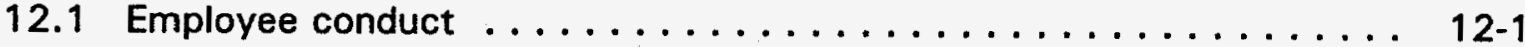

12.2 Emergency notification $\ldots \ldots \ldots \ldots \ldots \ldots \ldots \ldots \ldots \ldots \ldots \ldots$ 12-1

12.3 Fire: emergency response $\ldots \ldots \ldots \ldots \ldots \ldots \ldots \ldots \ldots \ldots \ldots$ 12-1

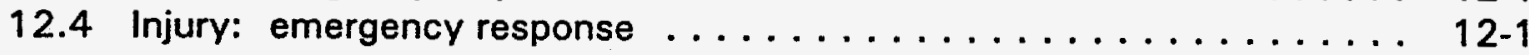

13.0 CHEMICAL WASTE CONTAINMENT AND SPILL CLEANUP $\ldots \ldots \ldots \ldots \ldots$ 13-1

13.1 Waste disposal procedures $\ldots \ldots \ldots \ldots \ldots \ldots \ldots \ldots \ldots \ldots \ldots$ 13-1

13.3 General procedures for facility liquid/solid wastes $\ldots \ldots \ldots \ldots \ldots$ 13-3

13.4 General procedure: spill cleanup $\ldots \ldots \ldots \ldots \ldots \ldots \ldots \ldots \ldots$ 13-4

13.4.1 Liquid waste cleanup . . . . . . . . . . . . . 13-4

13.4.2 Contamination containment .............. 13-4

13.5 General procedure: decontamination of spill area $\ldots \ldots \ldots \ldots \ldots 13-5$

14.0 WASTE DISPOSAL PROGRAM $\ldots \ldots \ldots \ldots \ldots \ldots \ldots \ldots \ldots \ldots \ldots$ 14-1

14.1 Guidance for waste management/disposal . . . . . . . . . . . 14-1

14.2 Liquid waste disposal $\ldots \ldots \ldots \ldots \ldots \ldots \ldots \ldots \ldots \ldots \ldots, 14-1$

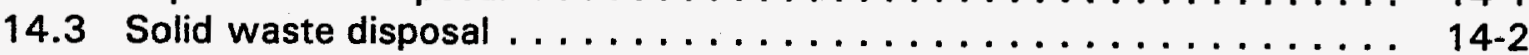

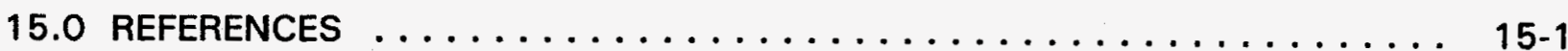

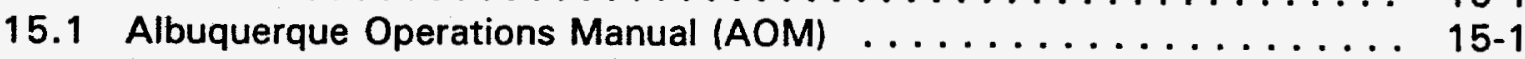

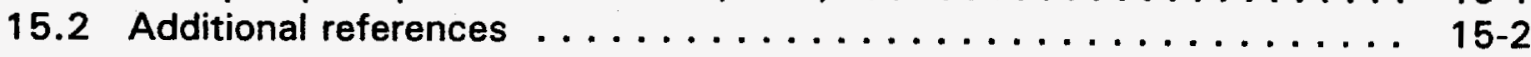




\section{LIST OF FIGURES}

Figure

Page

3.1 Schematic drawing of the U.S. Forestry Service facility . . . . . . . . . . 3-3

3.2 Schematic drawing of the UMTRA Project sample preparation facility area . . . . 3-4

11.1 Emergency evacuation routes from the UMTRA Project sample preparation facility ............................. 11-2

\section{LIST OF TABLES}

Table

Page

3.1 Summary of TAC UMTRA Project sample preparation facility units $\ldots \ldots \ldots$ 3-2

13.1 UMTRA Project analytes and their relative toxicity . . . . . . . . . . . 13-2 


\section{LIST OF ACRONYMS AND ABBREVIATIONS}

Acronym Definition

AOM

$\mathrm{CHO}$

DMA

EPA

$\mathrm{ft}^{2}$

JAM

$\mathrm{m}^{2}$

MSDS

OSHA

QA

QAIP

QAPP

SOP

TAC

UMTRA
Albuquerque Operations Manual

chemical hygiene officer

Data Management and Assessment

U.S. Environmental Protection Agency

square foot

Jacobs Acquisition Manual

square meter

Material Safety Data Sheet

Occupational Safety and Health Administration

quality assurance

Quality Assurance Implementation Plan

Quality Assurance Program Plan

standard operating procedure

Technical Assistance Contractor

Uranium Mill Tailings Remedial Action 


\subsection{PURPOSE}

In compliance with Occupational Safety and Health Administration (OSHA) standard 29 CFR \$1910.1450, this plan ensures that Technical Assistance Contractor (TAC) Uranium Mill Tailings Remedial Action (UMTRA) Project employees are informed of the presence and use of potentially hazardous chemicals in their work area. 


\subsection{SCOPE}

This plan shall apply to all users of the TAC UMTRA Project sample preparation facility (facility) at 2205 Columbia SE, Albuquerque, New Mexico. 


\subsection{CHEMICAL HYGIENE PLAN}

This plan was written to administer and monitor the practice of safety measures and chemical hygiene principles in the facility. It applies to toxic and/or hazardous substances or materials, whether organic or inorganic, and to radioactive materials regardless of their source. OSHA standard 29 CFR $\$ 1910.1450$, among others, requires persons administrating the use of chemicals, toxic substances, and radioactive materials to enforce certain standards for protection from those materials. No statement in this plan should be interpreted to vary from applicable law. Adherence to the rules and procedures set forth in this plan will ensure that chemicals, toxic substances, and radioactive materials are used safely and responsibly.

The facility manager, as designated by the manager of the TAC UMTRA Project Data Management and Assessment (DMA) Department, shall be responsible for implementing, enforcing, and complying with the provisions of this plan.

The chemical hygiene officer ( $\mathrm{CHO}$, as designated by the DMA department manager, shall be responsible for monitoring and enforcing provisions of this plan.

Individuals referred to in this plan as "manager," "officer," or "buyer" may, during an absence, delegate authority and responsibility to a colleague (delegee) or may assign certain duties to a subordinate (designee) as part of the subordinate's routine responsibility. Hence, the terms "manager," "officer," and "buyer" include such delegees and designees.

The facility consists of three units occupying 2963 square feet $\left(\mathrm{ft}^{2}\right)(275$ square meters $\left.\left[\mathrm{m}^{2}\right]\right)$ of the U.S. Forestry Service's Southwest Region Laboratory, located at 2205 Columbia SE, Albuquerque, New Mexico. Table 3.1 describes each unit. Figures 3.1 and 3.2 illustrate the layout of the U.S. Forestry Service Laboratory and the location of each facility unit within the U.S. Forestry Service Laboratory. 
Table 3.1 Summary of TAC UMTRA Project sample preparation facility units

\begin{tabular}{|c|c|c|c|}
\hline \multirow[t]{2}{*}{ Unit } & \multicolumn{2}{|c|}{ Area } & \multirow[t]{2}{*}{ Description } \\
\hline & $\mathrm{ft}^{2}$ & $m^{2}$ & \\
\hline Loading bay & $390(13)^{a}$ & 36 & $\begin{array}{l}\text { Store supplies or equipment, process } \\
\text { selected samples, and store } \\
\text { flammable/toxic chemicals in a locked } \\
\text { cabinet near door. Ship samples to } \\
\text { subcontract labs and equipment/ } \\
\text { supplies to TAC UMTRA Project field } \\
\text { sampling personnel. Contains shelves } \\
\text { for additional storage. }\end{array}$ \\
\hline Facility area & $462(16)^{a}$ & 42.9 & $\begin{array}{l}\text { Store labware, equipment, and } \\
\text { chemicals. Contains desk, filing } \\
\text { cabinet, benches, and instruments. }\end{array}$ \\
\hline Core storage area & $2111(71)^{a}$ & 196 & $\begin{array}{l}\text { Store drill cuttings, well development/ } \\
\text { testing and sampling equipment } \\
\text { (including sampling containers), soil and } \\
\text { water samples, and chemicals in } \\
\text { cabinets. Contains shelves for } \\
\text { additional storage and refrigerators to } \\
\text { store soil/water samples prior to } \\
\text { shipment and during limited sample } \\
\text { preparation or processing activities. }\end{array}$ \\
\hline
\end{tabular}

${ }^{a}(x x)=$ percent of total area occupied by unit.

$\mathrm{ft}^{2}=$ square feet

$\mathrm{m}^{2}=$ square meters 


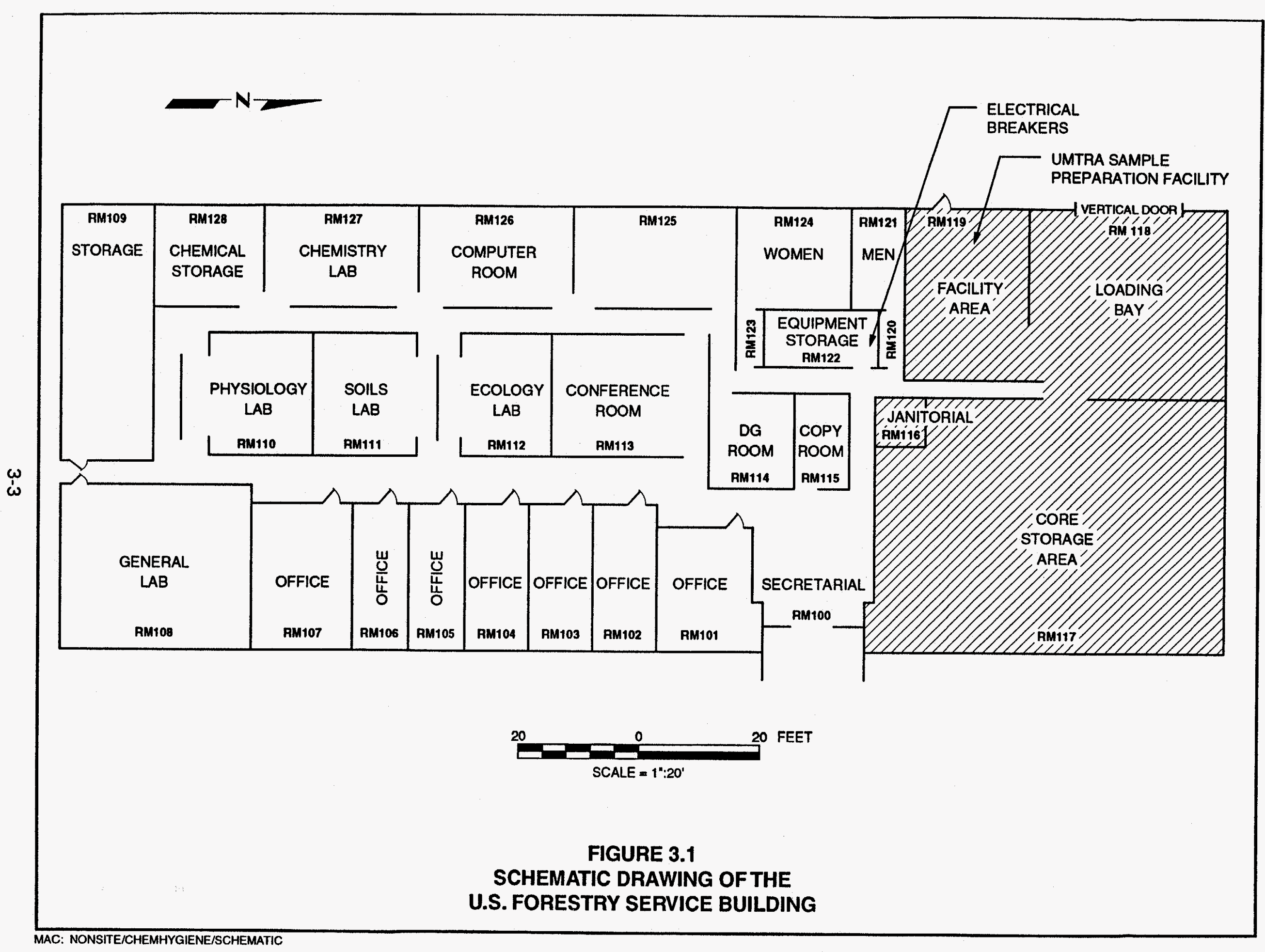




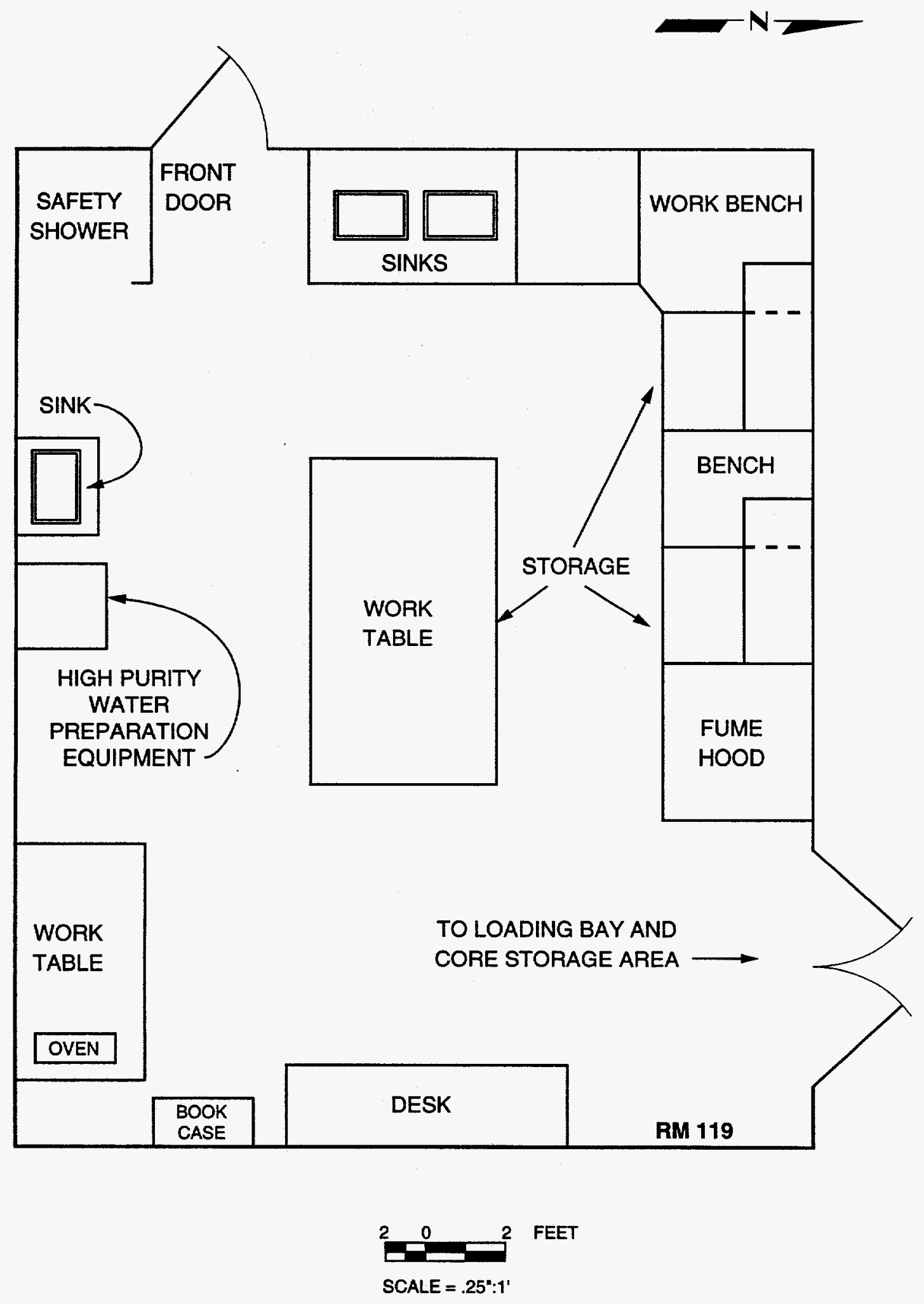

FIGURE 3.2

SCHEMATIC DRAWING OF THE UMTRA SAMPLE PREPARATION FACILITY U.S. FORESTRY SERVICE BUILDING 


\subsection{FACILITY USER TRAINING AND FACILITY RULES}

The sample preparation facility consists of the shipping and receiving area, the core storage area, and the sample and reagent preparation area.

\subsection{EMPLOYEE ORIENTATION}

Any work performed in the facility will be done by qualified, trained, and informed TAC personnel. Personnel will be trained (refer to Section 4.2) and informed before they are allowed to work in the facility.

- After orientation and training by the facility manager, the individual will be responsible for knowing the proper actions to take during emergencies such as fire, sample spills, evacuation.

- Any work assignment undertaken in the facility will be preceded by a briefing on the hazard involved. No job will be started until the worker is personally convinced of his/her safety. Employees will be encouraged to provide feedback with questions, suggestions, or comments they may have.

\subsection{FACILITY USER TRAINING}

\subsubsection{Briefings}

Facility user training will include briefings on the following topics:

- Health and safety practices, as outlined in the facility Chemical Hygiene Plan. The plan is located in the facility bookcase. The briefing will be documented on an "Employee Orientation" form.

- Material Safety Data Sheets (MSDSs) and their use. The MSDSs are contained in a notebook located in the facility bookcase.

- Work safety practices/toxic and hazardous chemicals currently in use in the facility. These briefings will be conducted by the facility manager or a member of the TAC Health and Safety Group and will be documented.

- Use of portable radiological monitoring instruments, if applicable to facility work.

- Directions for contacting the $\mathrm{CHO}$ for assistance.

\subsubsection{Specific task training}

In addition to the briefings described above, the facility user must be trained in the performance of the following procedures: 
- Accepted practices used to perform analyses in support of sample preparation activities.

- Performing calibration checks of measurement instruments and documenting data.

- Documentation of data related to samples (weight, volume, aliquots), calibration checks, calibration of solutions, instrument data displays, facility monitoring surveys, and other data required by the facility manager.

\subsection{FACILITY USER DUTIES}

It is the responsibility of the facility user to do the following:

- Practice facility chemical hygiene and safety rules when handling or storing samples, chemicals, toxic or hazardous substances, samples containing radioactive materials, and facility wastes.

- Ensure that the rules or procedures in the Chemical Hygiene Plan, UMTRA Project Quality Assurance Implementation Plan (QAIP), and the TAC Quality Assurance Program Plan (QAPP) are observed by all personnel using the facility.

- Post proper fire, safety, radiation, or chemical signs for work areas or as required by the facility manager.

- Maintain a current inventory of chemicals, equipment, and supplies.

- Submit samples to subcontract labs for analyses.

- Report all data to the appropriate UMTRA Project staff.

- Prepare and store toxic/hazardous solid or liquid wastes, solid or liquid wastes containing radioactive material, and other facility wastes for proper disposal.

- Maintain a clean facility.

\section{4}

\section{GENERAL FACILITY RULES}

In addition to following the guidelines outlined in Sections 4.1 through 4.3, facility users shall:

- Maintain a clear access to fire extinguishers and safety equipment, such as safety showers.

- Report all observed unsafe practices or conditions to the facility manager. 
- Refrain from eating, drinking, or smoking in the facility or storage areas. No cold storage of food for human consumption will be allowed.

- Wear glasses rather than contact lenses while working in the facility.

- Use personal protection equipment:

- Wear eye protection as required for specific jobs.

- Wear protective clothing whenever performing facility work (see Section 9.0).

- Report injuries as soon as practical, no matter how slight, to the facility manager (see Section 8.0 for other information on handling injuries).

- Immediately report any fires to the Albuquerque Fire Department by dialing 911.

- Post safety rules as specific as is considered necessary to prevent accidental injury. These rules are to be followed by employees and visitors alike.

\subsection{SPECIFIC FACILITY RULES}

Situations requiring specific rules are listed below.

\subsubsection{Safety rules}

- The $\mathrm{CHO}$ shall monitor or advise on any questionable situation.

- Walkways shall be kept clear of all obstructions.

- Combustibles and flammable materials shall be stored in a storage cabinet labeled "Flammable," except for gasoline, which will be stored in metal safety containers or in the fuel tanks of equipment.

- Guards shall be placed on hazardous moving equipment, such as motors, gears, belts and pulleys.

- Suitable equipment shall be used to handle or store hazardous chemicals.

- The elevated portable staircase shall be used for lifting heavy (40 pounds or more in weight) equipment or samples above head level. An alternate method is to use two or more persons.

- Leg rather than back muscles shall be used for lifting.

- Facility users shall stand clear of equipment being loaded or unloaded. 
- For moving equipment, a hand truck shall be used, as appropriate.

- Material carriers shall be pushed and not pulled.

- A second person shall assist with directing or opening doors when load or cart size becomes too large for easy management.

- Compressed air shall not be used to dust clothing or equipment or to clean work areas.

- Assume compressed gas cylinders are full and handle cylinders with care. NOTE: Always secure compressed gas cylinders.

\subsubsection{Chemical handling and storage}

- No pregnant woman shall work in the facility if she may be exposed to toxic substances or radioactive materials.

- All flammable reagents shall be stored in a cabinet designed and labeled for flammable storage.

- Do not assume the content of any unlabeled reagents. All containers shall be labeled at the time of preparation of the contents.

- Out-of-date or unlabeled chemicals or reagents shall not be used.

- Reagents shall not be mixed in sinks, drains, or traps.

- Wastes shall be neither mixed nor diluted before disposal.

\subsubsection{Personal health and safety}

- Facility users shall not bring unnecessary materials into the facility.

- Laboratory coats or coveralls shall be worn for handling chemicals.

- Pipettes shall be used with syringes or rubber bulbs or, preferably, shall have disposable tips. Users shall be prohibited from pipetting by mouth.

- All skin breaks shall be reported to the facility manager. Cuts shall be properly bandaged before user may enter any work station where contamination with toxic substances or radioactive materials is possible.

\subsubsection{Facility work}

- Persons entering the facility shall sign in for each visit, indicating the purpose of the visit and any equipment removed. 
- All work with toxic substances and radioactive materials shall be performed so as to confine the substances or materials within controlled boundaries. Areas where carcinogens and teratogens are in use shall be designated and controlled. Persons entering these areas shall be documented in logbook.

- All reactions involving fumes shall be conducted in the fume hood; before use, the hood shall be tested for sufficient positive air flow. Volatile or potentially volatile materials shall also be handled in the hood.

- Material immiscible with water (e.g., organics) shall not be poured into the facility sinks.

- All containers shall be clearly labeled. Appropriate warning signs, labels, or decals shall be used where practical when contained substance is toxic (see Section 11.0).

- Experimental chemical processes shall be attended at all times.

- Only trained users shall operate facility equipment and instruments. Facility manager shall be advised if any equipment needs repair.

- Spills shall be cleaned up as soon as possible. Hazards or potential hazards shall be corrected or reported to the facility manager.

- Work areas, equipment, and waste containers shall be surveyed immediately if suspected of radioactive contamination. If permissible levels are exceeded, decontamination procedures shall be implemented (see Section 13.0).

- Contaminated equipment and glassware shall be properly labeled and disposed of.

\subsubsection{Handling flammable solvents}

The following guidance is given so that standard practices can be used throughout the facility in the handling of flammable solvents. If special cases arise which are not covered by these practices, deviations from the following guidance must be approved in writing by the facility manager.

- Flammable solvents are classified as follows:

- Class 1 - Flash point below $100^{\circ} \mathrm{F}$.

- Class 2 - Flash point $100^{\circ}$ to $140^{\circ} \mathrm{F}$.

- Class 3 - Flash point $140^{\circ}$ to $200^{\circ} \mathrm{F}$. 
Flammable solvents in the facility with flash points in excess of $200^{\circ} \mathrm{F}$ are in the Class 3 category.

- Flammable solvents shall be used in the smallest quantity possible. A ventilation hood shall be used when available.

- Organic chemicals shall be used in minimum quantities and, when available, in the hood. If ventilation hoods are unavailable, facility manager must approve and post procedures defining permissible conditions for use of flammable solvent.

- If a Class 1 or Class 2 solvent is specially stored to maintain purity, additional safety storage is not required. The quantity of each specially stored solvent shall preferably be kept to under one liter.

- Glass containers shall be used to store solvent quantities of one (1) gallon or smaller. Metal and plastic containers may be used only when the solvent is known to be unreactive with these materials.

- All flammable solvent containers shall be plainly labeled "Flammable Solvent" with the name of the solvent.

- A five-pound, class $A B C$ fire extinguisher shall be readily available in the facility. In addition, a 10-pound $\mathrm{CO}_{2}$ or dry chemical fire extinguisher, or the equivalent, shall be placed within 20 feet of the facility door. Fire extinguishers located at the end of the shelves in the core sample storage area are adequate to meet this requirement.

- All electrical equipment must be grounded and inspected by the $\mathrm{CHO}$ for faulty connections, frayed wiring, etc., before using in a location where flammable solvents are being used. In an emergency, the electrical power to the room should be shut off by the main switch, which is located in equipment room 122 (see Figure 3.1).

\section{Glassware handling}

The following information and procedures shall be used as a guide for the use of glass items.

- Glassware shall be carefully inspected before use. Glassware with sharp edges, chips, cracks, poor connection, etc., shall be deposited in the "Glassware Disposal ONLY" container (see Section 13.2).

- To protect hands, leather gloves shall be worn for handling or manipulating glassware where breakage is a reasonable possibility. Glass rods or tubes shall be properly sized and lubricated if necessary for use with stoppers or flexible tubing. 
- Leather gloves and safety goggles or glasses shall be used to handle broken glass. Gloves shall be discarded if contamination is suspected.

- Safety glasses or goggles shall be used to assemble and use glass apparatus, clean glassware, handle broken glass, etc. (see Section 9.0).

- Glassware fabrication and repair may only be performed with the facility manager's authorization. Combustible or heat sensitive materials must be thoroughly removed from glass containers before any repair is attempted.

- Glassware with frozen joints, stopcocks, or stoppers shall be brought to the attention of the facility manager.

- Equipment designed to prevent breakage shall be used to transport glassware.

- Facility users shall be prohibited from carrying glassware improperly (e.g., by holding under arms or by glass-molded handles). Containers with suitable handles or grips shall be used.

- To minimize breakage, suitable storage facilities shall be provided for glassware.

- For pressure and vacuum equipment, all glass shall be reviewed for adequacy of design and for needed shielding.

- Extreme care and appropriate protective equipment shall be used to clean glassware. 


\subsection{CHEMICAL PROCUREMENT AND STORAGE}

\subsection{PROCUREMENT POLICY}

Chemicals, reagents, equipment, and supplies shall be requisitioned and purchased in accordance with the current edition of the Jacobs Acquisition Manual (JAM).

\subsection{RECEIPT OF CHEMICALS}

Chemicals, toxic substances, equipment, or other facility supplies shall be received at the TAC UMTRA Project offices or at the facility. It is the responsibility of the TAC representative involved in the procurement or other knowledgeable person to accept or reject a shipment of chemicals.

\subsubsection{Unacceptable shipments}

A shipment shall be rejected if:

- The cardboard box or other container is torn open, crushed, or cracked.

- The box or its containers emit obvious odors, discharge foreign dust-like material, or are stained with foreign material.

If the TAC representative determines a shipment to be unacceptable, he/she shall immediately refuse receipt of shipment and notify the $\mathrm{CHO}$. The $\mathrm{CHO}$ shall verify that the shipment is unacceptable, and the shipment shall be returned to the shipper.

The $\mathrm{CHO}$ shall instruct the shipper in the proper removal of the shipment from the UMTRA Project TAC offices. The CHO shall also determine a course of action for the cleanup and decontamination of affected areas.

\subsubsection{Documenting received shipments}

The TAC representative shall inform the facility manager of receipt of any chemicals. The facility manager shall do the following:

- Provide for the proper transmittal and storage of facility equipment and/or chemicals.

- Ensure that a Material Safety Data Sheet (MSDS), if required, accompanies each chemical or toxic substance. MSDSs provide toxicity, health, first aid, and other information on each chemical and are designed to aid in the cleanup of spills. See Section 5.3 for complete MSDS procedure. 


\subsection{CHEMICAL STORAGE PROCEDURES}

All chemicals shall be stored in the facility cabinets or in the fume hood in appropriate amounts and for reasonable periods of time. Each container shall be dated and labeled "Rec'd." Once opened, each container shall be labeled "Opened" and again dated. Chemical inventory and storage shall include the following:

- Inorganic chemicals and reagents.

- Organic chemicals and reagents.

- Toxic/hazardous chemicals or substances.

- Radioactive materials, if authorized.

Each chemical, reagent, or toxic/hazardous substance shall be stored in a cabinet in compliance with chemical compatibility/incompatibility guidelines. Cabinet bungs must be in place unless the cabinet contains outside vents.

\subsubsection{MSDS documentation}

If the chemical/reagent is accompanied by an MSDS, the MSDS shall be photocopied, the copy shall be kept in the MSDS notebook, and the original MSDS shall be submitted to the CHO. If an MSDS does not accompany the chemical/reagent, an MSDS should immediately be requested from the vendor.

Semiannually, the CHO's file of original MSDSs shall be checked against the facility notebook to ensure the accuracy and completeness of both.

\subsubsection{Acid storage}

Acids shall be stored as much as possible in the acid storage cabinet beneath the chemical fume hood. The cabinet shall be labeled to reflect the acids it stores, and the bottles will be placed in plastic basins, which will provide secondary containment.

\subsubsection{Flammable chemical storage}

Organics, solvents, and other flammable chemicals shall be stored and locked in the storage cabinet marked "flammable." Keys shall be kept at a predetermined location, and the cabinet should be located in a cool and accessible place.

\subsubsection{Light-sensitive chemical storage}

Light-sensitive chemicals shall be stored in cabinets or in dimly lit areas. These chemicals are usually contained in dark brown/amber bottles and should already be labeled as light-sensitive. 


\subsubsection{Chemical storage}

Chemicals will be stored in a segregated fashion: acids will be stored separate from bases; liquid reagents will be stored below dry reagents; secondary containment will be provided under acid bottles. 


\subsection{ENVIRONMENTAL MONITORING}

\subsection{PERSONNEL MONITORING}

The CHO may, at his/her discretion, require that personnel be tested to determine the extent of exposure to sample or chemical spills.

\subsubsection{External exposure}

Radiological materials are not handled as a normal part of facility activities. If such materials are to be handled, UMTRA Project health and safety staff and health physics staff will be consulted regarding the need for external monitoring.

\subsubsection{Internal exposure}

The TAC health and safety officer collects additional data for UMTRA Project personnel who may require monitoring by annual physical exams, bioassay, or other methods required by the UMTRA Project and/or OSHA.

\subsection{FACILITY MONITORING PROGRAM}

In accordance with Section 10.6.3 of the Albuquerque Operations Manual (AOM) and with the facility's formal inspection procedure (see Section 7.3), the facility shall be monitored periodically for radiological and other contamination. If chemicals or samples are spilled, if the facility's workload increases, or if results of routine monitoring require it, the facility manager and $\mathrm{CHO}$ will coordinate to perform more frequent surveys. The usual monitoring schedule shall resume when data indicate a return to pre-incident levels. See Section 13.5 for complete decontamination procedures. 


\subsection{HOUSEKEEPING, STORAGE, AND INSPECTION}

\subsection{HOUSEKEEPING}

The following housekeeping procedures shall be practiced throughout the facility. For more complete information on the safe handling of materials and equipment, see Section 4.0.

- Slipping hazards shall be reduced by keeping floors free of oil, grease, and water.

- Before use, container labels shall be checked for identification and special handling instructions, and containers shall be checked for damage and/or leakage. Faulty containers must be reported immediately to the facility manager.

- To prevent hand injury when handling sharp or caustic material, employees shall wear leather gloves.

\subsection{STORAGE}

- All acids and caustics must be stored below eye level.

- Shelved equipment shall not protrude into aisles.

- All material and equipment shall be safely ordered and stored in allocated locations.

- Large or heavy boxes shall be stored beneath small or light boxes.

- Stacked material shall always be moved from the top of the stack rather than the bottom.

\subsection{INSPECTION}

The facility manager or $\mathrm{CHO}$ shall formally inspect the facility once per quarter to determine compliance with the plan and shall then submit quarterly reports to the managers of the DMA and quality assurance (OA) departments. 


\subsection{MEDICAL PROGRAM}

\subsection{GENERAL REQUIREMENTS}

Facility users will have had first-aid training. First-aid kits throughout the facility shall be weatherproof containers with individually sealed packages for each type of treatment.

In the case of life-threatening or other serious injury, personnel will call 911 immediately to request an ambulance to transport the victim to the most convenient hospital. Victims whose injuries are less serious and who appear to be in stable condition shall be treated with available first aid and, if necessary, taken to nearby emergency room or urgent care facilities. As soon as is practical, all injuries will be reported to the facility manager. Emergency telephone numbers, including the 911 number, the numbers of nearby emergency rooms and urgent care facilities, and a map showing the locations of nearby emergency rooms and urgent care facilities shall be posted in a prominent location near the phone. Facility users will be advised of steps to take in an emergency and the above telephone numbers and treatment facility locations as part of facility user training.

All medical supplies and services shall conform with the practice standards of the American Medical Association.

\subsection{INVESTIGATIONS, REPORTS, AND RECORDS}

Use Sections 10.1.3 and 10.1.4 of the AOM (see Section 15.1). 


\subsection{PROTECTIVE APPAREL AND EQUIPMENT FOR REAGENT PREPARATION}

\subsection{PROTECTIVE APPAREL}

Personnel working in the facility shall use protective labwear, which includes but is not limited to the following:

- Washable/disposable lab coat or coveralls. Fabric must shed spilled liquids: absorbent clothing shall not be worn.

- Hat or hood to protect the head, hair, ears, and neck, when required.

- Face wear. At minimum, this shall include a face shield for handing base, toxic inorganic, radioactive, or organic solutions or for handling concentrated and diluted acids.

- Rubber apron for handling corrosive, hazardous, toxic, or radioactive solutions.

- Disposable gloves for handling acids, bases, toxic, radioactive, organics, or wastes. Forearm- or shoulder-length gloves or sleeve protectors shall be used to handle labwear or samples in deep containers. Gloves must be discarded into the proper solid waste container (see Section 13.3); waste containers shall conform to U.S. Environmental Protection Agency (EPA) storage and/or disposal requirements.

\subsection{PROTECTIVE EOUIPMENT}

The following protective equipment shall be used in the facility to minimize unanticipated emergency situations:

- Eye wash station: to immediately rinse the eyes with a prepared aqueous solution and reduce adverse interaction with eye tissues.

- Shower: to immediately remove the bulk of contaminant(s) from body surfaces.

- First aid kit: to treat abrasions, cuts, or burns.

- Spill kit: to neutralize acid or caustic solution spills.

The following equipment shall be used to minimize exposure to chemicals and other solutions:

- Chemical fume hood: to remove noxious odors, dusts, or fumes.

- Calibrated glass pipettes and bulbs: to eliminate pipetting by mouth. Calibrated pipettors and disposable pipette tips may also be used. 


\subsection{RECORDS}

The facility manager will establish and maintain the following records:

- MSDS. See Section 5.3.1 for complete procedure.

- AOM sections with standard operating procedures (SOPs) relevant to the facility.

- Sample logbook. Records data of samples processed in the facility le.g., aliquot weights for Batch and Column SOP) and provides archive of sample for future work.

- Facility instrument logbooks:

- Top loading balance logbook: records weight calibration data and repair and maintenance information.

- Analytical balance logbook: as above.

- Single beam balance logbook: as above.

- pH meter/electrode/conductivity meter logbook: records instrument calibration checks and repair and maintenance information.

- Facility survey logbook. Describes facility areas surveyed for spills or contamination purposes (see Section 6.2). Includes schematic drawings.

- Solid/liquid waste logbooks. See Section 13.3.

- Supplemental facility records:

- Chemical and reagent materials inventory: lists chemical, reagent, or radioactive materials used in the facility.

- Equipment inventory: lists equipment and/or supplies commonly used in the facility.

- Fume hood test results sticker on hood. Records hood air velocity: facility manager will contract for commercial hood testing with a velometer at least once per year.

Other TAC staff as described below will establish and maintain the following records:

- Radiological survey instrument logbook. Records of portable radiological survey instruments used and radiation surveys performed in the facility and storage areas. Logbook remains in the custody of a qualified UMTRA Project health physicist.

- Air sample logbook. Records of as-needed surveys of airborne radioactive contaminants in facility and storage areas, performed by TAC health physicist. Logbook remains in custody of the TAC health physicist and Health and Safety Group. 
- Personnel exposure record. See Section 6.1.

- Medical records. Records of accidents, injuries, illness, etc. See AOM for complete procedure. 


\subsection{SIGNS AND LABELS}

\section{$11.1 \quad$ SIGNS}

All facility users should be familiar with the facility's emergency evacuation route (see Figure 11.1).

Emergency notification signs shall be posted on the inside of the facility door and near the telephone. The signs must show the names and telephone numbers of individuals to contact in the event of a facility emergency or accident.

The following emergency-related signs will be posted to indicate the location of fire and safety aids:

- Fire safety aids.

- "Exit" signs to indicate direction of exit from the facility.

- Red signs to indicate location of fire extinguishers. Two fire extinguishers will be placed near the aisleway of the core sample storage area. One fire extinguisher will be placed in the facility proper.

- Safety aids: Green signs shall indicate the location of the eye wash station, shower, and first aid kit.

- Other fire/safety signs: Signs in all facility rooms shall indicate to firefighters or other emergency personnel the room's function and the extent of hazard in each room. Signs shall be posted in areas used to receive, ship, store, and process samples, chemicals, or supplies. These signs shall list the following information:

- Type and approximate quantity of chemicals and reagents.

- Special precautions to be observed.

- Name of person to notify in case of emergency.

Radiation warning signs shall be posted at any site where ionizing radiation may be present.

\subsection{LABELS}

Radioactive chemicals or samples must be specially labeled in light yellow with a magenta radiation symbol. These labels may be purchased from a safety supply house.

Whenever possible, prestamped labels shall be used for chemicals or samples. Labels must display required chemical hazard information and shall leave space for any necessary additional information. Individual labels shall be attached to the chemical, supplies, and samples, where practical. 


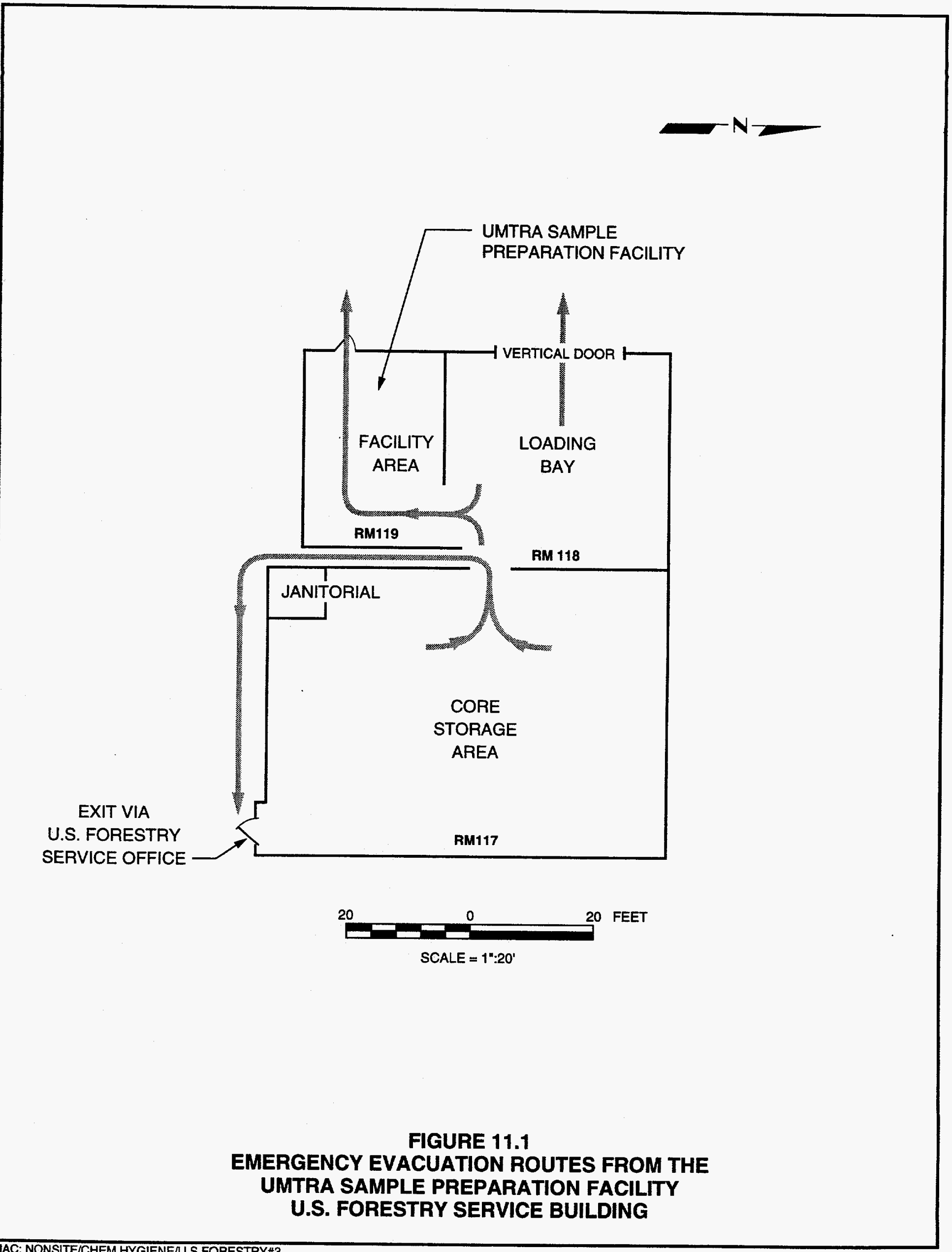


The following relevant information shall be printed clearly and legibly:

- Concentration, weight (or volume) per volume, preparer's initials, date, and matrix.

- For chemicals or samples containing radioactivity, concentration and radionuclide activity, date prepared or collected, and preparer's or collector's initials. 


\subsection{EMERGENCIES: FIRE AND INJURY}

\subsection{EMPLOYEE CONDUCT}

Facility users shall employ all reasonable caution when working alone and shall never work alone while performing operations requiring the handling of strong acids or bases.

\subsection{EMERGENCY NOTIFICATION}

In case of an emergency, the facility user shall contact the facility manager and $\mathrm{CHO}$. The $\mathrm{CHO}$, in consultation with the facility manager, shall contact the manager of the DMA Department and inform him/her of the emergency. The DMA department manager, in consultation with the $\mathrm{CHO}$, shall contact the Project Manager and inform him/her of the emergency.

\subsection{FIRE: EMERGENCY RESPONSE}

In case of fire within the building, a fire alarm will be set off by the person to discover the fire. Using the routes show in Figure 11.1, the facility shall be evacuated immediately. Facility users shall be trained to "walk, not run," to assemble at a designated outside spot, and to account for their co-workers.

\subsection{INJURY: EMERGENCY RESPONSE}

First aid shall be the immediate response to an injury in the facility. Employees may treat their own minor cuts, burns, or bruises from a first-aid kit. First-aid kits shall be available to all facility personnel. These kits shall be inspected periodically and their contents replenished as needed. Inspection shall be documented by labeling the kits with the inspection date and inspector's initials.

Serious accidents, such as deep cuts, stopped breathing, or loss of consciousness, require medical training. Facility users shall have Red Cross training in first aid or have completed a course in emergency medical training and shall know how to stop bleeding, prevent shock, detect bloodborne pathogens and perform artificial resuscitation and cardiopulmonary resuscitation. in case of these or any other medical emergencies, an ambulance shall be called as soon as possible. 


\subsection{CHEMICAL WASTE CONTAINMENT AND SPILL CLEANUP}

\subsection{WASTE DISPOSAL PROCEDURES}

Table 13.1 lists the analytes that may be required for facility investigations or experiments or that may be present in UMTRA Project soil, water, or other samples. Prepared solutions that have been used and become waste should be disposed of in accordance with the following procedures (see Section 13.3 for specific waste container labeling requirements):

- For organics such as toluene and benzene, waste containers shall be labeled "Organic Liquid Waste" or "Organic Solid Waste."

- If an organic solution is spilled, volatile and flammable organic solvents present the hazards of fire or explosion. All sources of heat or ignition must be extinguished immediately. If possible, ventilation shall be increased by opening windows and outside doors.

- Because the lab hood is not explosion-proof, it shall bear a warning label stating that throwing the switch may cause sparks. To avoid further spark hazard, no other electrical switches should be thrown until cleanup is complete.

- For calibrant solutions and distilled water wastes consisting of 1) pH buffer solutions for $\mathrm{pH}$ meters, 2) $\mathrm{KCl}$ solution(s) for conductance meters, and 3) solution or distilled water rinsates, waste containers shall be labeled "Dist. Water/Calibrant Liquid Wastes" or "Dist. Water/Calibrant Solid Wastes."

- For corrosive-type solutions $(\mathrm{pH} \leq 2$ or $\geq 12.5)$, respiratory protection is usually not needed, but disposable shoe covering and plastic gloves are useful.

- Acid solutions $(\sim 0.5 \underline{N}$ to $\sim 4 \underline{N})$ : waste containers shall be labeled "Acid Liquid Waste" and "Acid Solid Waste."

- Caustic solutions: $(\sim 1 \underline{N}$ to $\sim 10 \underline{N})$ : waste containers shall be labeled "Caustic Liquid Waste" and "Caustic Solid Waste."

- For special chemical solutions:

- Cyanide waste containers, if required, shall be labeled "Cyanide Liquid Waste, ONLY" and "Cyanide Solid Waste, ONLY."

- Ferri-/ferro-cyanide waste containers from Zobell Solution shall be labeled "Ferro-/Ferri- Cyanide Liquid Waste" and "Ferro-/Ferri- Cyanide Solid Waste."

- For toxic characteristic solutions with $\mathrm{As}, \mathrm{Cd}, \mathrm{Cr}, \mathrm{Pb}$, and/or $\mathrm{Se}$ : 
Table 13.1 UMTRA Project analytes and their relative toxicity

\begin{tabular}{|c|c|c|c|}
\hline Anions & Relative toxicity & Anions & Relative toxicity \\
\hline $\begin{array}{l}\text { Bicarbonate } \\
\text { Bromide }^{\mathrm{a}} \\
\text { Carbonate } \\
\text { Chloride }^{\mathrm{a}} \\
\text { Cyanide } \\
\text { Fluoride }\end{array}$ & $\begin{array}{l}(-) \\
(\mathrm{LH}) \\
(\mathrm{LH}) \\
(\mathrm{LH}) \\
(\mathrm{HH}) \\
(\mathrm{HH})\end{array}$ & $\begin{array}{l}\text { Nitrate } \\
\text { Nitrite } \\
\text { Nitrate and nitrite } \\
\text { Phosphate } \\
\text { Sulfate } \\
\text { Sulfide }\end{array}$ & $\begin{array}{l}\text { (HH) } \\
\text { (HH) } \\
\text { (HH) } \\
\text { (LH) } \\
\text { (LH) } \\
\text { (HH) }\end{array}$ \\
\hline Cations & & Cations & \\
\hline $\begin{array}{l}\text { Aluminum } \\
\text { Ammonium } \\
\text { Antimony } \\
\text { Arsenic + } \\
\text { Barium } \\
\text { Beryllium } \\
\text { Boron + } \\
\text { Cadmium } \\
\text { Calcium } \\
\text { Chromium + } \\
\text { Cobalt } \\
\text { Copper } \\
\text { Iron } \\
\text { Lead } \\
\text { Magnesium }\end{array}$ & $\begin{array}{c}\text { (LTH) } \\
(\cdots-) \\
\text { (HTH) } \\
(\text { HTH) } \\
\text { (HTH) } \\
\text { (HTH) } \\
\text { (LH) } \\
\text { (HTH) } \\
\text { (LTH) } \\
\text { (HTH) } \\
\text { (HTH) } \\
\text { (LTH) } \\
\text { (LTH) } \\
\text { (HTH) } \\
\text { (LTH) }\end{array}$ & $\begin{array}{l}\text { Manganese + } \\
\text { Mercury } \\
\text { Molybdenum + } \\
\text { Nickel } \\
\text { Potassium } \\
\text { Selenium + } \\
\text { Silver } \\
\text { Sodium } \\
\text { Strontium } \\
\text { Thallium } \\
\text { Tin } \\
\text { Uranium + } \\
\text { Vanadium + } \\
\text { Zinc }\end{array}$ & $\begin{array}{l}\text { (HTH) } \\
\text { (HTH) } \\
\text { (LTH) } \\
\text { (HTH) } \\
\text { (LTH) } \\
\text { (HTH) } \\
\text { (HTH) } \\
\text { (LTH) } \\
\text { (LTH) } \\
\text { (HTH) } \\
\text { (LTH) } \\
\text { (RH) } \\
\text { (HTH) } \\
\text { (LTH) }\end{array}$ \\
\hline Other & & Other & \\
\hline $\begin{array}{l}\text { Gross alpha } \\
\text { Gross beta } \\
\text { Lead-210 } \\
\text { Polonium-210 } \\
\text { Radon-222 } \\
\text { Radium-226 }\end{array}$ & $\begin{array}{l}\text { (RH) } \\
\text { (RH) } \\
\text { (RH) } \\
\text { (RH) } \\
\text { (RH) } \\
\text { (RH) }\end{array}$ & $\begin{array}{l}\text { Radium-228 } \\
\text { Silica } \\
\text { Thorium-230 } \\
\text { Total dissolved solids } \\
\text { Total organic carbon }\end{array}$ & $\begin{array}{c}(\mathrm{RH}) \\
(-) \\
(\mathrm{RH}) \\
(-) \\
(-)\end{array}$ \\
\hline
\end{tabular}

aMay form oxyhalides under certain chemical conditions; $+=$ may form oxyanions under certain chemical conditions and be determined as oxyanions. Such oxyanalytes should be reduced and precipitated for waste disposal purposes, whenever required.

LTH = low toxic hazard.

HTH = high toxic hazard.

$\mathrm{LH}=$ low hazard in terms of toxicity, oxidant, flammability, and explosivity.

$\mathrm{HH}=$ high hazard in terms of toxicity, oxidant, flammability, and explosivity.

$\mathrm{RH}=$ radiological hazard in terms of toxicity, concentration, and dose.

$(-)$ or $(--))=$ unknown. 
- Waste containers for solutions containing non-radioactive analytes shall be labeled "Special Analyte Liquid Waste" and "Special Analyte Solid Waste."

- UMTRA Project site ground water: waste containers shall be labeled as "Radioactive Ground Water Liquid Waste" and "Radioactive Ground Water Solid Waste."

- UMTRA Project site ground water containing non-radioactive analytes (see Table 13.1): waste containers shall be labeled as "Ground Water Analyte Liquid Waste" and "Ground Water Analyte Solid Waste."

- For clothing contaminated with naturally-occurring radionuclides $(\mathrm{Pb}-210$, Po-210, Ra-226, Th-230, or U-234/-238), waste container shall be labeled "Contaminated Clothing and Misc. Items."

- Liquid mercury use for facility activities is discouraged, as spilled mercury tends to form small, rolling droplets that are difficult to see and find. Special spill kits for mercury are commercially available and will be purchased prior to use of mercury. The kit consists of a vacuum device for picking up large droplets, sponges for small droplets, and a powder that amalgamates whatever mercury is left. Waste container shall be labeled "Mercury Waste."

- For glassware, a metal container shall be labeled "Glassware, ONLY" and used for unusable glass bottles or broken glass labware.

\subsection{GENERAL PROCEDURES FOR FACILITY LIQUID/SOLID WASTES}

- Waste containers shall be labeled " Liquid Waste" and " Solid Waste." Blank lines shall be filled in with the name of the waste material.

- Approximate volume or weight of liquid or solid wastes to be disposed of shall be recorded in supplemental facility logbook (see Section 10). This also applies to spilled liquids or solids.

- Liquids or solids, including spills and material used for cleanup, shall be deposited into the proper waste container.

- Proceed with Section 16.2.6 of the AOM (see Section 15.1).

All waste containers shall be emptied at the end of each work day. Exceptions shall be those containers used to collect and store liquid or solid wastes and containers with glass; those containers shall be emptied whenever directed by the facility manager. 


\subsection{GENERAL PROCEDURE: SPILL CLEANUP}

Small chemical spills do not generally constitute a facility emergency. They are easily mopped up, absorbed by paper or cloth, and discarded into the proper container. However, larger chemical spills may be considered an emergency, especially if the chemical is hazardous. The following procedure shall be used for spill cleanup:

- If a chemical spill occurs, the chemical must be identified immediately.

- Facility manager, or $\mathrm{CHO}$ if manager is unavailable, must be notified of spill as soon as possible. See Section 12.2 for notification procedure.

- Until specific instructions are received from facility manager or $\mathrm{CHO}$, user shall do the following:

- Refer to Section 13.1 to determine correct waste container. Volume or weight of spill must be recorded (see Section 13.3).

- Use MSDS for each chemical, reagent, or analyte known to be in the spilled liquid/solid to determine proper safety procedures and method and material for cleanup.

- Determine necessary protective gear, such as disposable shoe covers or gloves.

\subsubsection{Liquid waste cleanup}

- Cleanup shall begin only after the proper survey and decontamination equipment has been obtained.

- Spill pillows, which are porous, inert plastic cushions filled with highly absorbent fumed silica, are stored in a labeled cabinet. With the exception of hydrofluoric acid, spill pillows will pick up all chemicals and may be purchased at a safety supply house.

- Liquid waste shall be collected and discarded into the proper liquid waste container (see Section 13.2). Cleanup materials shall be discarded in the proper solid waste container and any residue mopped up with detergent and water.

\subsubsection{Contamination containment}

- If radiological materials are involved, facility users shall not leave the contaminated area until they are surveyed with radiological survey instruments and samples (environmental or bioassay) are obtained.

- No one shall enter the contaminated area until cleanup is complete. 


\subsection{GENERAL PROCEDURE: DECONTAMINATION OF SPILL AREA}

- Affected area shall first be decontaminated by washing with soap (or other detergent) and water. Acid/base or other strong cleaning agents may require dilution; the facility manager can provide necessary guidance. The proper method of decontamination will take into account the nature of both the spill and the contaminated surface.

- Disposable rags, paper towels, or other sorbent material shall be used with decontamination solution to decontaminate and clean the area of the spill. Decontamination materials shall be discarded as solid waste.

- For spills containing only radioactive materials, the area must be cleaned as prescribed by a TAC health physicist. Facility users shall refer to Section 10.6.3 of the AOM (see Section 15.1). Spill material and waste must be disposed of in proper containers (see Section 13.2).

- For samples or solutions containing toxic or hazardous substances, spill area shall be carefully cleaned and the $\mathrm{CHO}$ or facility manager shall be notified.

- Decontamination shall continue until the $\mathrm{CHO}$ inspects and approves the spill area. 


\subsection{WASTE DISPOSAL PROGRAM}

\subsection{GUIDANCE FOR WASTE MANAGEMENT/DISPOSAL}

Albuquerque city ordinances prohibit discharge of contaminated liquid wastes.

- It is illegal to dispose of any radioactive materials, including uranium-bearing solutions, into the sewer system (Ordinance 8-9-3H, "Limitations on Radioactive Wastes").

- It is illegal to dispose of waste solutions containing more than $40 \mathrm{mg}$ total metals/L into the sewer (Ordinance 8-9-3M, "Limitations on Pollutant Concentration"). pH of solution should be neutral.

\subsection{LIQUID WASTE DISPOSAL}

Liquid wastes may be prepared for disposal by the following methods.

- Entire collected volume of wastes may be sent to 1) UMTRA Project Ambrosia Lake burial site or 2) New Mexico RCRA disposal site, Mountainair, or 3) an approved RCRA burial site in conformance with NMEID requirements. To ship liquid waste:

- Plastic jar shall be filled with vermiculite or equivalent.

- Jar shall then be filled with as much liquid waste as the vermiculite will absorb, the lid tightened and sealed with plastic tape.

- Jar shall be labeled with contaminant(s), quantity, and date.

- Liquid waste volume may be reduced by evaporation if toxic/hazardous analyte will not be emitted and, if required, shall be recycled.

- Toxic/hazardous analytes may be precipitated from the wastes. Decantate and filtrate may be discarded only if solution contains $\leq 40 \mathrm{mg}$ total metals/liter of solution.

- Before the decantate is discarded, a sample must be analyzed by a subcontract laboratory.

- After precipitate is properly contained, disposal procedure may resume. 


\subsection{SOLID WASTE DISPOSAL}

Solid wastes may be prepared for disposal by the following methods.

- Weight and chemical form of solid residue or precipitate shall be recorded on the proper container.

- Sample or sample residue shall be packaged securely in a plastic bag or jar.

- Package shall be labeled with contaminant(s), quantity, and date.

- Proceed with paragraph 13.0 of Section 16.2.6 of AOM.

- Amount of waste shall be recorded before being sent to an approved disposal site (e.g., Ambrosia Lake or New Mexico RCRA disposal site, Mountainair). An ongoing record of all solid waste disposal--radioactive and non-radioactive (i.e., toxic/hazardous)--shall be maintained. 


\subsection{REFERENCES}

\subsection{ALBUQUERQUE OPERATIONS MANUAL (AOM)}

The following sections of the AOM apply in whole or in part to this plan.

- Section 4.2, "Smoking in the Work Place."

- Section 7.1, "UMTRA Project Environmental Health and Safety Plan."

- Section 7.2, "TAC Environmental Health and Safety Plan."

- Section 9.2.3, "Training."

- Section 9.2.7, "Personnel Training and Qualifications Documentation and Records Procedure."

- Section 10.1, "Administrative Procedures."

- Subsection 10.1.1, "Implementation of ALARA Program."

- Subsection 10.1.2, "Radiation Safety Officer: Authority and Responsibility."

- Subsection 10.1.3, "Emergency Notification."

- Subsection 10.1.4, "Unusual Occurrence Reporting Guidelines."

- Subsection 10.6.1, "Equipment Contamination Survey."

- Subsection 10.6.2, "Personnel Contamination Survey."

- Subsection 10.6.3, "Laboratory Smear Survey."

- Section 16.1.6, "Soil-Water Sampler Installation and Sample Collection."

- Section 16.1.8, "Batch and Column Leach Testing."

- Section 16.1.10, "Field Measurements of Water Samples for Temperature; Conductivity, pH, Alkalinity, and Total Acid."

- Section 16.1.11, "Sample Collection for Organic Substances."

- Section 16.1.13, "Field Determination of Oxidation and/or Reduction Potential (ORP) in Water Samples."

- Section 16.2.1, "Sample Collection, Preservation, and Shipment of Water Samples." 
- Section 16.2.2, "Water Sampling for Tritium Analysis."

- Section 16.2.3, "Evaluation of Chemical Analysis of Water Samples."

- (Proposed) Section 16.2.5, "Classification of Wastes and Preparation of Waste Containers."

- (Proposed) Section 16.2.6, "Treatment and/or Disposal of Hydro facility Wastes."

- (Proposed) Section 16.2.7, "Special Treatment Methods for Facility Wastes."

\subsection{ADDITIONAL REFERENCES}

The following documents also apply to this plan.

- CFR (Code of Federal Regulations), 1990. Protection of the Environment, Volume 40, Parts 260 to 270. Offices of the Federal Register, National Archives and Records Administration, Washington, D.C.

- CFR (Code of Federal Regulations), 1990. "Labor", Volume 29, Part 1910. Offices of the Federal Register, National Archives and Records Administration, Washington, D.C.

- DOE (U.S. Department of Energy), 1989. Technical Approach Document, Revision II, December, 1989. UMTRA-DOE/AL-050425.0002, DOE UMTRA Project Office, Albuquerque, New Mexico.

- Furr, A. Keith, 1991. CRC Handbook of Laboratory Safety, 3rd Edition. CRC Press, Ann Arbor, Michigan

- NRC et al. (National Research Council; Committee on Hazardous Substances in the Laboratory, Assembly of Mathematical and Physical Sciences), 1990. Prudent Practices for Handling Hazardous Chemicals in Laboratories, September, 1990. National Academy Press, 2101 Constitution Avenue, N.W., Washington, D.C. 20418

- NRC et al. (National Research Council, Committee on Hazardous Substances in the Laboratory, and Committee on Physical Sciences, Mathematics, and Resources), 1990. Prudent Practices for.Disposal of Chemicals from Laboratories, November, 1989. National Academy Press, 2101 Constitution Avenue, N.W., Washington, D.C. 20418 